\title{
Erratum to: Reflections on the Jābāli Episode in the Vālmīki Rāmāyaṇa (Ayodhyākāṇ̣̣a)
}

\author{
Ramkrishna Bhattacharya ${ }^{1}$
}

Published online: 12 September 2015

(C) Springer Science+Business Media Dordrecht 2015

\section{Erratum to: J Indian Philos DOI 10.1007/s10781-015-9278-3}

The original publication of the article includes some errors which were overlooked. The corrections are given below.

On Page 1, line 9 of the abstract section, the word epistemology, should read as epistemology. [comma to be deleted]

On Page 2, last line of the last paragraph, the word $\boldsymbol{M B h}$ should read as $\boldsymbol{M b h}$. In footnote 1 , the sentence that read as, the worst of the negativists should read as 'the worst of the negativists'.

On Page 3, footnote 3 lines 3-4, the sentence 'Such is a thief, such a Buddhist; know that in this the Tathagata and Nastika are included,' although should be read as "A Buddhist [or the Buddha, buddhah] is like a thief; and know that a Cārvāka is (like) a Buddhist" [tathägata, so Cm] $(2241 * .14-15$; this is apparently the only occurrence of the word buddha in the $R \bar{a} m$ tradition). Jābāli thereafter responds $(2249 *=2241 * .21-26)$ with the denial that he is a Cārvāka, and declares that he only spoke as he did to win Rāma over.' However.

On Page 13, line 9, the words "are insertions" should be read as "is an insertion". On Page 14, line 3 of Paragraph 2, the words, "this fact" should be read as "the very existence of the critical edition".

The online version of the original article can be found under doi:10.1007/s10781-015-9278-3.

Ramkrishna Bhattacharya

carvaka_rkb@yahoo.com; ramkrishna.bhattacharya@gmail.com

1 Pavlov Institute, 98, Mahatma Gandhi Road, Kolkata 700 007, India 
The missing reference for the citation Bulcke C, should read as Bulcke, C. (1993). Rāmakathā: utpatti aur vikāsa. Ilahabad: Hindi Parishad, Prayaga Vishvavidyalaya (first pub. 1950).

On page 16, the text in reference 18, "BSBhBrahma-sūtra-bhāṣya Adviata should read as Advaita. On Page 18, reference, Rām 1844..., the word Bvana should read as Gaudana. On page 19, reference Vasudevahiṃ̣ī should read as Vasudevahiṃ̣̂̄. In the reference Vātsyāyana..., the words Kāmasūtra Jayamañgalā should read as Kāmasūtra Jayamamgalā. On Page 19, reference Subhashitaratnabhandagara..., the word "Deilli" should read as "Dilli".

The references $\boldsymbol{S V M}, \boldsymbol{P P u}$ (2), Hazra, R. C. (3), Mallișeṇa (1) and Thakur, A. (1) should be ignored as these should have been removed from the article. 